\title{
Evaluation of composition and performance of composts derived from guacamole
}

\section{production residues}

J. Jorge González-Fernández ${ }^{\mathrm{a}}$, Zesay Galea ${ }^{\mathrm{b}}$, José M. Álvarez ${ }^{\mathrm{c}}$, J. Iñaki Hormaza ${ }^{\mathrm{a}}$, Rafael López ${ }^{b^{*}}$

anstituto de Hortofruticultura Subtropical y Mediterránea 'La Mayora' (IHSM-

UMA-CSIC), 29750-Algarrobo-Costa, Málaga, Spain, jorgegonzalez-

fernandez@eelm.csic.es

${ }^{b}$ Instituto de Recursos Naturales y Agrobiología de Sevilla (IRNAS-CSIC), P.O. box 1052, 41080-Sevilla, Spain

${ }^{c}$ Composting Advisor. Hierbaluisa 21, 41089 Montequinto, Sevilla, Spain

*Corresponding author: R. López

Phone: +34954624711

Fax: +34954624002

e-mail: rlnunez@irnase.csic.es

\begin{abstract}
The utilization of organic wastes to improve soils or for growth media components in local farms and nurseries can reduce the environmental pollution linked to waste disposal while increasing the sustainability of crop production. This approach could be applied to waste products generated from the production
\end{abstract}


of guacamole (an emerging activity in the avocado production areas in mainland Spain), where appropriate treatment of this oily and doughy waste product has not been previously reported. The aim of this work is to study the feasibility of cocomposting guacamole production residues (GR) with garden pruning waste (PW) as bulking agent, and the possible use of the compost produced depending on its quality. A windrow composting trial using three GR:PW ratios, 2:1, 1:2, and 1:7 was carried out. Temperature, moisture, organic matter, and $\mathrm{C} / \mathrm{N}$ ratio were used to follow the evolution of the composting process during 7 months. After an additional 3-month curing period, composts were sieved to less than $10 \mathrm{~mm}$ and a set of European quality criteria was used to assess compost quality and intended use. In general, the 3 composting mixtures followed the classical process evolution, with minor differences among them. The 1:2 GR:PW ratio appeared most adequate for combining better process evolution and maximum GR ratio. Except for their high $\mathrm{pH}$ that limits their use as growing media component in some particular cases, the obtained composts fulfilled the more stringent European standards for commercial composts. Self-heating tests confirmed the high stability of the composts produced. The germination of cress by the direct contact method was satisfactory for composts GR:PW 1:2 and 1:7, showing no signs of toxicity. Avocado seedlings planted in substrates containing $67 \%$ of the GR:PW composts exhibited greater plant growth than those in the control treatment, and with no signs of phytotoxicity. The results open an interesting opportunity for the sustainable treatment of avocado fruit by-products derived from guacamole and avocado oil processing.

Keywords: avocado, composting, guacamole waste, nursery growing media, pruning residues 


\section{Introduction}

Large quantities of liquid and solid residues are produced in the processing of fruits and vegetables that together can account for $93 \%$ of all residues generated by the food processing industry (Hang, 2004). This includes fruit and vegetable peels, seeds, pits, cakes, tofu whey, different kinds of process water, and wastewater treatment sludge. The liquid waste is usually disposed of in sewers, whereas most solid wastes are returned to the land for disposal, often illegally dumped, or recycled (Hang, 2004).

The rate of avocado (Persea americana Mill.) cultivation has been growing worldwide during the last decades with a total world production of 4.36 million tons in 2012, twice as much as in 1999 (FAOSTAT, 2014). Although avocados are usually consumed as fresh fruits, in salads and avocado-based cuisine, the consumption of minimally processed products, such as guacamole (a sauce made with mashed avocado pulp seasoned with various condiments), or the use of avocado oil for cosmetics and cooking is increasingly growing worldwide.

Avocado processing often generates significant amounts of wastes. In Mexico, the leading avocado producing country, 5\% of the fruits produced in 2008 were destined for processing (mainly for guacamole) resulting in a total amount of approximately 20,000 tons of generated residues (Dorantes-Alvarez et al., 2012). The main reason for this is that the exocarp and seed accounts for up to $30 \%$ of the fruit dry weight in commercial avocado cultivars. Although these by-products could have commercial interest due to their richness in phytochemical substances (Bost et al., 2013), they are usually discarded causing problems with pollution at disposal sites. 
In Spain, the only country in Europe with a significant commercial production of avocados, guacamole production is an emerging activity in avocado production areas. As a result of this activity, residues from guacamole production (GR), consisting of peels, seeds and pulp are increasing and, if not properly treated, could become a significant environmental concern.

Composting of organic wastes such as those derived from fruits and vegetables is considered one of the best treatment options from both an economic and an environmental point of view. The composting process reduces toxicity, volume, and moisture content of residues and transforms them into interesting sources of organic matter for agricultural use. Therefore, composting of GR could become an opportunity to increase the sustainability of the production of some local crops with good responses to organic amendments, including avocado. The results obtained could also be of interest for the treatment of residues produced from avocado oil extraction. Despite this interest, the composting of avocado guacamole and oil residues has not been reported. A likely reason for this may be that the doughy texture and oily composition of avocado residues makes their composting difficult.

The effectiveness of recycling residues as soil conditioners or fertilizers depends on their chemical ( $\mathrm{pH}$, soluble salts, $\mathrm{C} / \mathrm{N}$ ratio, nutrient contents, heavy metals, and specific toxicants), physical (bulk density, hydrophysical properties, odour) and biological (presence of pathogens) properties, site characteristics, and the crop. The aim of this work was to study the feasibility of composting GR as a way to obtain high quality composts. The effect of the GR:PW volume ratio was also considered. Following the most recent guidelines to evaluate compost quality, selected chemical characteristics and standard European tests for compost 
characterization were used to evaluate several possible uses of GR-based compost.

\section{Materials and Methods}

\subsection{Composting feedstock}

The characteristics of raw materials used for composting are shown in Table 1. GR was obtained from Avomix Factory located in Vélez-Málaga (Málaga province, Spain). It consists of peels and seeds, with a reduced amount of plastic residues. As can be observed in Table 1, GR was a moist material, with a $\mathrm{C} / \mathrm{N}$ ratio of 56 due to the abundance and large size of avocado seeds. PW was obtained from chipped pruning waste coming from private and public gardens in Vélez-Málaga. The PW was an abundant and heterogeneous residue, composed of several plant residues with palm and pine tree components being particularly apparent. The maximum particle size was $15 \mathrm{~cm}$. At the time of starting the composting trial, this residue was slightly moistened due to rainfall. It presented a $\mathrm{C} / \mathrm{N}$ ratio of 74 due to its woody character. This product was incorporated as a structuring agent to balance the mushy consistency of GR. Poultry manure (M) was also included in composting mixes as a source of available nitrogen for microorganisms. Aged manure was obtained from a nearby chicken egg farm; due to the previous storage period, this residue was rather mineralized having a high salinity (electrical conductivity), low organic matter $(\mathrm{OM})$ content and a $\mathrm{C} / \mathrm{N}$ ratio of 10 . 
Table 1 Characteristics of the composted materials: guacamole production solid residues (GR), green waste (PW) and poultry manure (M)

\begin{tabular}{llrlrlrl}
\hline & Unit & \multicolumn{2}{c}{ GR } & \multicolumn{3}{c}{ PW } & \multicolumn{2}{c}{ M } \\
\hline Dry matter & $\mathrm{g} \mathrm{kg}^{-1}$ & 319.2 & $(4.2)^{\mathrm{a}}$ & 606.2 & $(20.8)$ & 745.9 & $(40.2)$ \\
$\mathrm{BD}^{\mathrm{b}}$ & $\mathrm{g} \mathrm{L}^{-1}$ & 230.2 & $(5.1)$ & 103.8 & $(49.7)$ & 670.3 & $(56.6)$ \\
$\mathrm{pH} \mathrm{1:5} \mathrm{vol}$ & & 7.06 & $(0.06)$ & 6.40 & $(0.04)$ & 7.83 & $(0.08)$ \\
$\mathrm{EC}^{\mathrm{c}} 1: 5 \mathrm{vol}$ & $\mathrm{mS} \mathrm{m}^{-1}$ & 83.3 & $(6.6)$ & 39.0 & $(2.7)$ & 611.3 & $(19.9)$ \\
$\mathrm{OM}^{\mathrm{d}}$ & $\mathrm{g} \mathrm{kg}^{-1}$ & 951.4 & $(5.3)$ & 923.3 & $(17.7)$ & 156.9 & $(11.0)$ \\
$\mathrm{OC}^{\mathrm{e}}$ & $\mathrm{g} \mathrm{kg}^{-1}$ & 551.8 & $(3.1)$ & 535.5 & $(10.3)$ & 91.0 & $(6.4)$ \\
$\mathrm{Kjeldahl-N}$ & $\mathrm{g} \mathrm{kg}^{-1}$ & 9.81 & $(0.33)$ & 7.28 & $(0.48)$ & 9.19 & $(0.60)$ \\
$\mathrm{C} / \mathrm{N}$ & & 56.3 & $(1.6)$ & 73.8 & $(5.5)$ & 9.9 & $(0.3)$
\end{tabular}

${ }^{\mathrm{a}}$ Values in brackets are standard deviation, $\mathrm{n}=3$; ${ }^{\mathrm{b}} \mathrm{BD}$ : Compacted bulk density on a dry matter basis; ${ }^{\mathrm{c}} \mathrm{EC}$ : Electrical conductivity; ${ }^{\mathrm{d}} \mathrm{OM}$ : Organic Matter; ${ }^{\mathrm{e}} \mathrm{OC}$ : Total Organic Carbon

\subsection{Composting piles}

The selected system to carry out the trial was windrow composting. Three composting piles were prepared with the following volume ratios of the components described above: 2:1:0.125, 1:2:0.125, 1:7:1 for GR:PW:M respectively. The piles will be coded as GR2PW1, GR1PW2 and GR1PW7 for simplicity. The ratios with greater GR residue (2:1:0.125 and 1:2:0.125) were selected in order to maximize GR ratio in the compost. The mix 1:7:1 was assayed to assess the tolerance of the composting process to wide changes in feedstock ratios. Initially, the three mixes (including all particle sizes) showed similar $\mathrm{C} / \mathrm{N}$ ratios: 46, 47 and 45 for GR2PW1, GR1PW2 and GR1PW7 respectively.

The dimensions of the piles were $4 \mathrm{~m}$ long, 2-3 $\mathrm{m}$ wide and $1.5 \mathrm{~m}$ high. The piles were built with the aid of a front-loading tractor using the shovel for the volumetric measurement of the wastes. The wastes were deposited on alternate layers of GR and PW, spraying the required volume of M on each layer. Water was gradually added onto each layer to avoid leaching. The residues were mixed 
and re-watered when turning over the piles. The experiment was initiated on May 4, 2012 and composting piles were turned 5 times on days 41, 83, 123, 167 and 220. A suitable time of turning was selected according to the evolution of the temperature within the piles, which were recorded every 2-3 days using a digital thermometer equipped with a $1 \mathrm{~m}$ long probe. The probe was inserted in 6 positions per pile, taking the temperature readings at 50 and $100 \mathrm{~cm}$ deep. After the last turning event, the composts were left for an additional 3-month curing period.

\subsection{Compost sampling}

Raw materials were sampled when the compost piles were built while compost samples were collected from each pile at the start of the composting experiment, after each turning of the piles, and at the end of the maturation period. Separate samples were collected in three positions per pile, making a trial pit and taking the sample in the whole depth. Each single sample was about $10 \mathrm{~L}$. It was assumed that large pieces of wood and avocado seeds would slowly decompose during the composting trial. The samples corresponding to composting evolution and final product were separated into two size fractions using a $10 \mathrm{~mm}$ sieve. Both size fractions were weighed and analysed separately. If necessary, the complete sample composition was calculated from the weighted average. For whole samples of raw materials, all sized particles were analysed.

\subsection{Compost chemical analysis and maturity tests}

Compost samples were analysed following standard procedures for soil improvers and growing media of the European Committee for Standardization (CEN). Moisture and laboratory compacted bulk density were determined 
following EN 13040 (CEN, 1999d). The results were expressed on a dry matter basis. Fresh compost samples were used for the determination of electrical conductivity and $\mathrm{pH}$ in a 1:5 (v:v) aqueous extract (CEN, 1999a, b). Nitrate-N and ammonium-N contents were determined in fresh samples by spectrophotometry in a flow autoanalyser (AA III, Bran+Luebbe, Norderstedt, Germany) after a 1/5 (v/v substrate/extracting solution) extraction using calcium chloride/DTPA as extracting solution (CEN, 2001). In dried and ground samples, the organic matter content $(\mathrm{OM})$ was determined by dry combustion at $450^{\circ} \mathrm{C}(\mathrm{CEN}, 1999 \mathrm{c})$ and total $\mathrm{N}$ content was determined by distillation after Kjeldahl digestion. Organic carbon content (OC) was calculated from $\mathrm{OM}$ by multiplying by the factor 0.58 . Watersoluble OC was determined using a TOC analyser (Simadzu TOC-VCSCH) after water extraction following the procedure indicated by Paradelo et al. (2013).

Mineral nutrients and trace element contents were determined after aqua regia digestion in a microwave oven by ICP-OES (CEN, 2002). Compost samples from the WEPAL programs (Houba et al., 1996) were also analysed for quality control of analytical procedures. The results obtained for these samples agreed $\pm 5 \%$ with the certified results.

Final composts (particle size $<10 \mathrm{~mm}$ ) were subjected to common stability and toxicity tests. A self-heating test (Brinton et al., 1995) was done with compost at $75 \%$ water holding capacity. A germination test with cress (Lepidium sativum) (CEN, 2011b) was performed in Petri dishes by the direct contact method. Seed germination and root length were measured $72 \mathrm{~h}$ after sowing. The germination rate (GR), the root length index (RLI) (root length relative to the control) and the Munoo-Liisa Vitality Index (MLV) (which compares the product of germination rate and the average root length in the test and control samples) were calculated as follows: 


$$
\begin{gathered}
G R(\%)=\frac{\text { number of germinated seeds in compost }}{\text { mean number of germinated seeds in control }} \times 100 \\
R L I(\%)=\frac{\text { root lenght in compost }}{\text { mean root lenght in control }} \times 100 \\
M L V(\%)=\left[\frac{G R_{i} \times R L I_{i}}{\operatorname{mean}\left(G R_{c} \times R L I_{c}\right)}\right] \times 100
\end{gathered}
$$

Where $\mathrm{GR}_{\mathrm{i}}$ and $\mathrm{RLI}_{\mathrm{i}}$ are the results corresponding to each compost replicate and $\mathrm{GR}_{\mathrm{c}}$ and $\mathrm{RLI}_{\mathrm{c}}$ are the corresponding to the control sample.

For the determination of plant response, a growth bioassay with Chinese cabbage (Brassica rapa ssp. pekinensis) (CEN, 2011a) was carried out. Plants were cut 23 days after sowing. A commercial fertilized peat-based substrate, which incorporated $1.5 \mathrm{~kg} \mathrm{~m}^{-3}$ of 14:7:15 N:P:K fertilizer (14:16:18 as $\mathrm{N}: \mathrm{P}_{2} \mathrm{O}_{5}: \mathrm{K}_{2} \mathrm{O}$ ) was used as control treatment in the germination and growth tests.

\subsection{Avocado seedling production trial}

Composts were used in a planting experiment of avocado seeds cv. TopaTopa, commonly used as a seedling rootstock for avocado in Spain. Seeds were germinated in substrates of each compost and perlite (2:1 in volume). A common mixture in avocado nurseries, made of coconut fibre (50\%), peat (17\%) and perlite (33\%), was used as control treatment. Each treatment consisted of 30 black polyethylene bags $(7.5 \mathrm{~cm}$ diameter x $30 \mathrm{~cm}$ height $)$ which were randomly distributed inside a nethouse. As the experiment was designed for a short period of time after seed germination, when avocado seedlings could still grow using nutrients stored in the seed, fertilizer was not incorporated into the compost mixtures or to the control substrate. Three months after sowing, plants were evaluated by counting the number of leaves and measuring plant height and stem 
diameter at $4 \mathrm{~cm}$ from the stem base. Leaf area of each plant was also calculated by drawing leaf outlines and measuring their area with a Delta-T Area Meter.

\subsection{Statistical analysis}

Analyses of variance (ANOVA), considering the type of compost as independent factor, were performed for the variables measured. Equality of variance was checked using Levene's test. LSD test or multiple comparison of means by the 'post-hoc' Tukey test was carried out. A significance level of $\mathrm{P}<$ 0.05 was used throughout the study. All statistical analysis was carried out with the program SPSS 19 for Windows (SPSS, 2010).

\subsection{Compost evaluation}

There is a wide range of criteria concerning compost quality, classification and use. As a rule of thumb the most restrictive criteria were used for classifying the obtained guacamole-composts. In most EU countries, the basic restrictions usually concern the permissible heavy metal content (compost class) which may lead to establishing the direct metal load limitation $\left(\mathrm{g} \mathrm{ha}^{-1} \mathrm{y}^{-1}\right)$, in most cases calculated on a basis of 2 to 10 years, or to restrict the admissible dosage of dry

matter compost per ha and year. In the present case, due to the 'clean' nature of the wastes used, the European eco-label criteria for soil improvers (EuropeanCommission, 2006) were used for comparing heavy metal contents as it sets low permissible levels for metals in general (Brinton, 2000).

Salinity (measured as EC) and $\mathrm{pH}$ are considered key properties to allow compost use in nurseries and greenhouses (Tittarelli et al., 2007). Ammonium is considered to be phytotoxic when exceeding a certain threshold, which is stricter under nursery use due to close contact between the compost and the plant root 
systems. These properties were evaluated following the Waste and Resources Action Programme guidelines for compost use in growing media (WRAP, 2011), because they are based in the same European standardized analytical methods used in this work. Some countries have undertaken the restrictions according to a maximum nutrient supply (phosphorus or nitrogen) to land or to agricultural crops. Other properties were discussed using recently reported end-of-wastecriteria (Barth et al., 2008; IPTS, 2012) or were compared with those reported in the literature for similar systems.

\section{Results and Discussion}

3.1.Temperature evolution during the composting process

The evolution of daily temperatures for each compost pile during the composting process is shown in Fig. 1. The temperature evolution was similar for the three compost piles but their relative order changed in the periods between pile turning $(41,83,123,167$, and 220 days, indicated in the graph as a vertical dotted line). Temperature readings were taken 3 days after the initial construction of the piles. At this time, the GR2PW1 pile reached $52^{\circ} \mathrm{C}$, while piles with higher proportion of PW (GR1PW2 and GR1PW7) exceeded $60^{\circ} \mathrm{C}$. This is probably because the composting process had already started during the short storage period of PW. Jurado et al. (2014) also observed temperature values higher than $60{ }^{\circ} \mathrm{C}$ around $48 \mathrm{~h}$ after the beginning of the plant waste composting process. Initially, the temperature reached a maximum $\left(65-68^{\circ} \mathrm{C}\right)$ in the three piles during days 5-10 and then began to decrease. The composting process started soon after pile building indicating that the most biodegradable constituents of the residues had been quickly and easily transformed. After pile turning at day 41, the 
temperature increased again indicating the reactivation of the composting process. Maximum temperatures similar to previous readings were observed in all the three composting piles $\left(66-68^{\circ} \mathrm{C}\right)$. From this time the temperature decreased almost continuously in the GR1PW7 pile and no reactivation of the composting process was observed after further turning of the compost. During the whole composting period, the average temperature in the GR1PW7 pile was $4^{\circ} \mathrm{C}$ lower than the averages in the GR2PW1 and GR1PW2 piles (Table 2). This could suggest that the amount of biodegradable OM in GR1PW7 (with low GR ratio) responsible for the maintenance of the composting process was limited. In the GR2PW1 and GR1PW2 piles a new subsequent reactivation (temperature increase) was observed after day 83 and after day 123, although the temperatures reached were below the previous maximum temperatures observed in both piles. Pile turning at day 167 failed to produce any significant additional heat generation. After this date, heavy rainfall induced excess moisture within the piles. In order to facilitate their drying, the piles were turned once again although no subsequent temperature increase was observed. In the GR2PW1 and GR1PW2 piles, taking into account pile dimensions and structure, the active degradation phase could be considered complete after turning the piles 3 times based on observed temperatures.

\section{[INSERT Fig 1 HERE]}

Mean temperatures for each time period and relevant information for each pile are shown in Table 2. Before the first turning (day 0-41), the mean temperature was higher in the GR1PW2 and GR1PW7 piles than in the GR2PW1 pile, while between the first and the second turning (day 41-83) the order of the piles according to the mean temperature was GR1PW2 $\approx$ GR2PW1 $>$ GR1PW7. From 
the third turning (periods between days 123-167 and 167-220) the order of the piles according to the mean temperatures was GR2PW1 > GR1PW2 > GR1PW7. The data suggests that -a fraction of- the PW residue was readily biodegradable and that the presence of the GR residue caused a delay in the active composting phase. The reason for the resistance of GR to degradation may lie in its chemical composition. Avocado seeds contain high levels of polyphenols (Soong and Barlow, 2004) that could inhibit microorganism growth. The doughy character of GR could have also reduced pile aeration in the case of GR2PW1. This hypothesis is reinforced by temperature differences observed at 100 and $50 \mathrm{~cm}$ deep (table 2). The temperature at a depth of $100 \mathrm{~cm}$ in the GR1PW2 and GR1PW7 piles was 6.2 and $9.9^{\circ} \mathrm{C}$ higher than at $50 \mathrm{~cm}$. In the GR2PW1 pile, maximum temperature difference reached between both depths was only $0.6^{\circ} \mathrm{C}$. This suggests that deep aeration in the GR2PW1 pile could have been limited.

Table 2 Time evolution of the average temperature in each compost pile and number of days above target temperature

\begin{tabular}{|c|c|c|c|c|c|}
\hline Period (day) & & GR2PW1 & GR1PW2 & GR1PW & \\
\hline $0-41$ & & $56.1 \mathrm{a}$ & $60.1 \mathrm{~b}$ & 60.3 & $\mathrm{~b}$ \\
\hline $41-83$ & & $59.3 \mathrm{~b}$ & $60.6 \mathrm{~b}$ & 56.9 & $\mathrm{a}$ \\
\hline $83-123$ & & $48.4 \mathrm{~b}$ & $51.7 \mathrm{c}$ & 43.5 & $\mathrm{a}$ \\
\hline $123-167$ & & $45.9 \mathrm{c}$ & $43.5 \mathrm{~b}$ & 35.5 & $\mathrm{a}$ \\
\hline $167-220$ & & $30.1 \mathrm{c}$ & $26.7 \mathrm{~b}$ & 23.0 & $\mathrm{a}$ \\
\hline $0-220$ & & $45.2 \mathrm{~b}$ & $45.5 \mathrm{~b}$ & 41.0 & $\mathrm{a}$ \\
\hline $\mathrm{T}>55^{\circ} \mathrm{C}$ & days & 60 & 83 & 58 & \\
\hline $\mathrm{T}>60^{\circ} \mathrm{C}$ & days & 19 & 37 & 29 & \\
\hline $\mathrm{T}>65^{\circ} \mathrm{C}$ & days & 3 & 16 & 4 & \\
\hline $\mathrm{T}_{100}-\mathrm{T}_{50}$ & $\max ^{a}$ & 0.6 & 6.2 & 9.9 & \\
\hline
\end{tabular}


The generation of adequate temperature profiles during GR composting is of key importance because avocado pulp and minimally processed products are prone to pathogen growth due to their neutral $\mathrm{pH}(6.7)$. The main pathogens that could be present in avocado fruits are Listeria monocytogenes, Salmonella and Clostridium botulinum (Dorantes-Alvarez et al., 2012; Iturriaga et al., 2002). Food industries take the necessary measures to prevent microbial contamination but these measures apply only to the main food product and not to production residues. Reaching elevated temperatures during the composting process will result in sanitization of the final product. The exposure time and temperature to inactivate relevant pathogens for windrow composting should be at least a period of 2 weeks at $55^{\circ} \mathrm{C}$ (Böhm, 2007) although different regulatory guidelines regarding the necessary length of time at elevated temperatures can be found (Brinton, 2000; Ceustermans et al., 2010). In the three piles, temperature was maintained above $55^{\circ} \mathrm{C}$ (Table 2) for 8 to 12 weeks fulfilling the requirement mentioned above. Alternative guidelines (Brinton, 2000) use the limit of $65^{\circ} \mathrm{C}$ maintained for 3 to 7 days. In this case, GR1PW2 compost was maintained above $65^{\circ} \mathrm{C}$ more than 2 weeks, while in the GR2PW1 and GR1PW7 composts, the indicated temperature was maintained for 3-4 days. Taking into consideration the reduced experimental size of the piles, it could be assumed that in slightly larger composting piles, the more restrictive sanitization criteria would be met.

Primary pathogens (E. coli and Salmonella spp.) were assessed in final compost samples by analysis in a private laboratory. $E$. coli was no detected ( 0 MPN g ${ }^{-1}$ ) in the three compost samples and Salmonella was absent in $25 \mathrm{~g}$ of sample. These results confirmed the safety of the compost according to EU regulations (European-Commission, 2006). 
3.2.Moisture evolution during the composting process

Optimal moisture content in the starting material is variable and fundamentally depends on the physical state and size of the particles. Normally, a $60 \%$ moisture content in the starting material is satisfactory, and a minimum of $40 \%$ during composting is recommended (Diaz and Savage, 2007). At the start of the composting process, PW and M were relatively dry (Table 1) due to their previous storage. Water was therefore added when building the composting piles to reach moisture contents above $50 \%$ in piles GR2PW1 and GR1PW2, and a lower content (43.4\%) in the GR1PW7 pile (Table 3). Additional water was added when piles were turned at 41,83 and 123 days, and rainfall incorporated additional water until the end of the composting process (see Fig. 1). After pile turning (days 41-220), the moisture contents were $\sim 65 \%$ in the GR2PW1 and GR1PW2 piles and $~ 55 \%$ in the GR1PW7 pile. Anaerobic conditions were not observed during the composting process. In general, moisture content in the piles GR2PW1 and GR1PW2 were $10 \%$ higher than in pile GR1PW7. The bulking agent PW, which was in a greater ratio in the GR1PW7 pile, created an open structure limiting the water holding capacity of the materials. Although this study was not designed to determine optimum moisture contents, the results do not indicate that there was a lack or an excess of moisture during the composting process.

\subsection{Organic matter degradation}

During composting, OM content decreased in the three composts (Fig. 2). The rate of OM degradation was greater in compost GR1PW7 than in GR1PW2 and GR2PW1. The lower GR/PW ratio or the greater M ratio in the GR1PW7 compost could have favoured a faster and more intense composting process. For the whole 
process, OM degradation in the GR1PW2 and GR2PW1 composts were similar; however, during the initial phase of composting (days 0-83), the degradation rate for compost GR1PW2 was more evident than for GR2PW1 (Fig. 2). The rate sequence GR1PW7 > GR1PW2 > GR2PW1 agreed to the described trends for the evolution of temperature (Section 3.1).

Table 3 Moisture (\%) evolution during composting in each pile

\begin{tabular}{|c|c|c|c|c|}
\hline Process day & GR2PW1 & GR1PW2 & GR1PY & \\
\hline 0 & $59.6 \mathrm{c}$ & $52.9 \quad \mathrm{~b}$ & 43.4 & $\mathrm{a}$ \\
\hline 41 & $66.7 \mathrm{c}$ & 60.9 & 55.1 & $\mathrm{a}$ \\
\hline 83 & 58.7 a & 62.1 & 55.3 & $\mathrm{a}$ \\
\hline 123 & $65.8 \mathrm{~b}$ & 65.2 & 56.7 & $\mathrm{a}$ \\
\hline 167 & $66.6 \mathrm{~b}$ & 67.8 & 58.3 & $\mathrm{a}$ \\
\hline 220 & $68.3 \mathrm{c}$ & 66.1 & 54.5 & $\mathrm{a}$ \\
\hline 308 & $55.7 \mathrm{c}$ & 46.5 & 32.0 & $\mathrm{a}$ \\
\hline
\end{tabular}

Values in the same line followed by the same letter are not statistically different (Tukey test, $\mathrm{p}<0.05)$

Despite significant differences observed for OM content amongst the three composts, $\mathrm{C} / \mathrm{N}$ ratio evolution was similar, particularly in composts GR1PW2 and GR2PW1 (Fig. 2). In those composts, the $\mathrm{C} / \mathrm{N}$ ratio decreased sharply from 47 to 21 and from 45 to 22 during the 83-day period. Paradelo et al. (2013) found that most changes in waste characteristics took place within the first two to three months of winery wastes composting. These authors indicated low degradability and potential difficulties for composting lignocellulosic wastes, due to their high $\mathrm{C} / \mathrm{N}$ ratio and lignin content. As a consequence, they found scarce evolution of the parameters related to total $\mathrm{OM}$ which did not allow the use of these parameters to monitor the process of composting. In this study, the classical parameters related to $\mathrm{OM}$ evolution were adequate to monitor the composting process. 


\section{[INSERT Fig 2 HERE]}

In the GR1PW7 compost, $\mathrm{C} / \mathrm{N}$ ratio decreased from 44 to 19 during the same period. After this time, $\mathrm{C} / \mathrm{N}$ ratio change was slow and virtually the same for all three composts (Fig. 2). Considering $\mathrm{C} / \mathrm{N}<20$ as maturity criteria (Itavaara et al., 2010), the three guacamole composts could be considered as mature enough after a 3 month active composting period and two turnings. Open structure in compost piles due to PW would facilitate aeration and limit the number of necessary turnings.

The maturity of the final products is also shown by the water-soluble OC to total $\mathrm{N}$ ratio (Table 4) which was lower than the value 0.55 suggested as threshold limit value (Chang et al., 2006).

Emissions were not measured during the composting process - no noticeable odour was detected. The low $\mathrm{N}$ content $\left(<10 \mathrm{~g} \mathrm{~kg}^{-1}\right.$, Table 1$)$ in the composting substrates makes high nitrogenous emissions $\left(\mathrm{NH}_{3}, \mathrm{~N}_{2} \mathrm{O}\right)$ unlikely (Chou and Büyüksönmez, 2006).

\subsection{Chemical characteristics and intended uses of the end products}

After the 3-month curing period, the composts were screened through a 10 $\mathrm{mm}$ sieve. The fine-graded $(<10 \mathrm{~mm})$ and coarse $(>10 \mathrm{~mm})$ fractions were separated and analysed. The coarse fractions of each compost type were separately analysed although, due to the fact that similar results were obtained for all of them, the average characteristics for the coarse fraction are shown (Table 4). The coarse fraction represented $47 \%$ of the GR2PW1 compost, $37 \%$ of the GR1PW2 compost and 31\% of the GR1PW7 compost (Table 4). This fraction consisted of the large seeds of the avocado fruits (87.2\% in coarse GR2PW1, 
$34.2 \%$ in coarse GR1PW2 and $26.0 \%$ in coarse GR1PW7) and woodchips.

Those results suggest that increasing the GR:PW ratio would result in a greater percentage of the coarse fraction in the final compost due to the seeds of avocado fruits. The elevated $\mathrm{C} / \mathrm{N}$ ratio (44) of the coarse fraction indicated that its constituents were un-decomposed. The plant nutrient and heavy metal contents in the coarse fraction were lower than those in the fine-graded compost (Table 4). Depending on PW availability and price, the coarse fraction could be re-circulated to the composting process or used as mulch for weed control (Grundy and Bond, 2007) because its characteristics fit into those needed for mulches: coarse nutrient-poor compost with low content of fine particles (Carlsbaek, 2010). This would be easily implemented in the guacamole production area of Southern Spain where several potential users exist for mulch such as tropical crops, which cover more than 18.000 ha, and private and public gardens.

Chemical characteristics of fine-graded compost are shown in Table 4. The three composts had an alkaline $\mathrm{pH}$, which although in the upper range usual for composts, can normally be observed in composts. The GR2PW1 and GR1PW2 composts surpassed the limit ( $\mathrm{pH}$ 9) suggested by WRAP (WRAP, 2011) for compost use in growing media. The optimum $\mathrm{pH}$ for plant growing media ranges between 5.5 and 6.5. The WRAP limit takes into account that compost in growing media is diluted by other substrate components, suggesting ranges between $5-50 \%$ by volume for high quality green compost to be mixed with peat or other suitable low nutrient, low conductivity substrates (IPTS, 2012; WRAP, 2011). In this case, due to the high $\mathrm{pH}$ values of the composts obtained, if they are included in growing media, special care should be taken to limit the total amount applied to each container. The electrical conductivity (EC) (Table 4) was about one third of the maximum allowable for use as growing media component 
(WRAP, 2011). The low EC of guacamole-derived composts does not impede nursery uses. It is likely that intense rainfall episodes during composting (Fig. 1)

Table 4. Characterization of composts and their particle size fractions $(<10 \mathrm{~mm}$ and $>10 \mathrm{~mm})$ after the maturation period

\begin{tabular}{|c|c|c|c|c|c|c|}
\hline & Unit & GR2PW1 & GR1PW2 & GR1PW7 & & limit \\
\hline Moisture $^{a}$ & $\mathrm{~g} \mathrm{~kg}^{-1}$ & $557 \mathrm{~b}$ & $465 \mathrm{~b}$ & $320 \mathrm{a}$ & -- & $50^{\mathrm{g}}$ \\
\hline $\mathrm{BD}^{\mathrm{b}, \mathrm{a}}$ & $\mathrm{g} \mathrm{L}^{-1}$ & $263 \mathrm{a}$ & $297 \mathrm{a}$ & $483 \mathrm{~b}$ & -- & $550^{\mathrm{g}}$ \\
\hline$>10 \mathrm{~mm}^{\mathrm{a}}$ & $\%$ & 47.0 & 36.9 & 30.8 & -- & \\
\hline$<10 \mathrm{~mm}^{\mathrm{a}}$ & $\%$ & 53.0 & 63.1 & 69.2 & -- & \\
\hline \multicolumn{2}{|c|}{ SIZE FRACTION } & $<10 \mathrm{~mm}$ & $<10 \mathrm{~mm}$ & $<10 \mathrm{~mm}$ & $>10 \mathrm{~mm}^{\mathrm{c}}$ & \\
\hline \multicolumn{2}{|l|}{$\mathrm{pH} 1: 5 \mathrm{v}: \mathrm{v}$} & $9.18 \mathrm{~b}$ & $9.12 \mathrm{~b}$ & $8.93 \mathrm{c}$ & -- & $9.0^{\mathrm{g}}$ \\
\hline \multicolumn{2}{|c|}{$\mathrm{EC}^{\mathrm{d}} 1: 5 \mathrm{v}: \mathrm{v} \mathrm{mS} \mathrm{m}{ }^{-1}$} & $57.0 \mathrm{~b}$ & $49.3 \mathrm{ab}$ & $40.3 \mathrm{a}$ & -- & $150^{\mathrm{g}}$ \\
\hline $\mathrm{OM}^{\mathrm{e}}$ & $\mathrm{g} \mathrm{kg}^{-1}$ & $466 \mathrm{~b}$ & $431 \mathrm{~b}$ & $259 \mathrm{a}$ & $892 \mathrm{c}$ & \\
\hline$O C^{f}$ & $\mathrm{~g} \mathrm{~kg}^{-1}$ & $270 \mathrm{~b}$ & $250 \mathrm{~b}$ & $150 \mathrm{a}$ & $517 \mathrm{c}$ & \\
\hline $\mathrm{OCw}^{\mathrm{i}}$ & $\mathrm{g} \mathrm{kg}^{-1}$ & $6.75 \mathrm{ab}$ & $5.44 \mathrm{ab}$ & $2.83 \mathrm{a}$ & $10.40 \mathrm{~b}$ & \\
\hline \multicolumn{2}{|c|}{ Kjeldahl-N g kg ${ }^{-1}$} & $18.4 \mathrm{c}$ & $15.6 \mathrm{~b}$ & $9.3 \mathrm{a}$ & $11.8 \mathrm{~b}$ & \\
\hline \multicolumn{2}{|l|}{$\mathrm{C} / \mathrm{N}$} & $14.6 \mathrm{a}$ & $16.0 \mathrm{a}$ & $16.2 \mathrm{a}$ & $43.8 \mathrm{~b}$ & \\
\hline \multicolumn{2}{|l|}{$\mathrm{OCw} / \mathrm{N}$} & $0.37 \mathrm{a}$ & $0.35 \mathrm{a}$ & $0.31 \mathrm{a}$ & $0.88 \mathrm{~b}$ & \\
\hline $\mathrm{NH}_{4}-\mathrm{N}$ & $\mathrm{mg} \mathrm{L}^{-1}$ & $2.3 \mathrm{a}$ & $2.3 \mathrm{a}$ & $4.0 \mathrm{a}$ & -- & $50^{\mathrm{g}}$ \\
\hline $\mathrm{NO}_{3}-\mathrm{N}$ & $\mathrm{mg} \mathrm{L}^{-1}$ & $61.7 \mathrm{c}$ & $14.3 \mathrm{a}$ & $46.6 \mathrm{~b}$ & -- & \\
\hline $\mathrm{P}$ & $\mathrm{g} \mathrm{kg}^{-1}$ & $9.08 \mathrm{~b}$ & $9.55 \mathrm{~b}$ & $17.0 \mathrm{c}$ & $3.69 \mathrm{a}$ & \\
\hline K & $\mathrm{g} \mathrm{kg}^{-1}$ & $11.7 \mathrm{~b}$ & $9.74 \mathrm{ab}$ & $8.32 \mathrm{a}$ & $8.32 \mathrm{a}$ & \\
\hline $\mathrm{Ca}$ & $\mathrm{g} \mathrm{kg}^{-1}$ & $50.9 \mathrm{~b}$ & $64.6 \mathrm{~b}$ & $90.9 \mathrm{c}$ & $24.0 \mathrm{a}$ & \\
\hline $\mathrm{Mg}$ & $\mathrm{g} \mathrm{kg}^{-1}$ & $8.48 \mathrm{~b}$ & $9.52 \mathrm{bc}$ & $12.1 \mathrm{c}$ & $4.66 \mathrm{a}$ & \\
\hline $\mathrm{Na}$ & $\mathrm{g} \mathrm{kg}^{-1}$ & $0.695 \mathrm{a}$ & $0.788 \mathrm{a}$ & $1.009 \mathrm{a}$ & $0.658 \mathrm{a}$ & \\
\hline $\mathrm{Fe}$ & $\mathrm{g} \mathrm{kg}^{-1}$ & $10.0 \mathrm{ab}$ & $12.9 \mathrm{~b}$ & $13.7 \mathrm{~b}$ & $5.62 \mathrm{a}$ & \\
\hline $\mathrm{Cu}$ & $\mathrm{mg} \mathrm{kg}^{-1}$ & $32.0 \mathrm{~b}$ & $32.0 \mathrm{~b}$ & $42.8 \mathrm{c}$ & $16.2 \mathrm{a}$ & $100^{\mathrm{h}}$ \\
\hline $\mathrm{Mn}$ & $\mathrm{mg} \mathrm{kg}^{-1}$ & $267 \mathrm{~b}$ & $314 \mathrm{~b}$ & $485 \mathrm{c}$ & $135 \mathrm{a}$ & \\
\hline $\mathrm{Zn}$ & $\mathrm{mg} \mathrm{kg}^{-1}$ & $172 \mathrm{~b}$ & $156 \mathrm{~b}$ & $280 \mathrm{c}$ & $65 \mathrm{a}$ & $300^{\mathrm{h}}$ \\
\hline $\mathrm{Cd}$ & $\mathrm{mg} \mathrm{kg}^{-1}$ & $0.183 \mathrm{~b}$ & $0.157 \mathrm{~b}$ & $0.220 \mathrm{~b}$ & $0.05 \mathrm{a}$ & $1^{\mathrm{h}}$ \\
\hline $\mathrm{Cr}$ & $\mathrm{mg} \mathrm{kg}^{-1}$ & $46.3 \mathrm{a}$ & $51.4 \mathrm{a}$ & $58.5 \mathrm{a}$ & $48.6 \mathrm{a}$ & $100^{\mathrm{h}}$ \\
\hline $\mathrm{Ni}$ & $\mathrm{mg} \mathrm{kg}^{-1}$ & $26.2 \mathrm{a}$ & $26.5 \mathrm{a}$ & $31.8 \mathrm{a}$ & $21.0 \mathrm{a}$ & $50^{\mathrm{h}}$ \\
\hline $\mathrm{Pb}$ & $\mathrm{mg} \mathrm{kg}^{-1}$ & $6.4 \mathrm{ab}$ & $9.0 \mathrm{ab}$ & $17.2 \mathrm{~b}$ & $4.5 \mathrm{a}$ & $100^{\mathrm{h}}$ \\
\hline
\end{tabular}

${ }^{\mathrm{a}}$ Results correspond to the whole compost; ${ }^{\mathrm{b}}$ Compacted bulk density on a dry matter basis; 'Average values for coarse samples from the three composts;

${ }^{\mathrm{d}} \mathrm{EC}$ : electrical conductivity; ${ }^{\mathrm{e}} \mathrm{OM}$ : Organic Matter; ${ }^{\mathrm{f}} \mathrm{OC}=$ Total Organic Carbon; ${ }^{\mathrm{g}}$ Maximum permissible limit following WRAP guidelines; ${ }^{\mathrm{h}}$

Maximum permissible limit following EU eco-label for soil improvers;

--, not determined; ${ }^{\mathrm{i}} \mathrm{OCw}=$ Water-soluble $\mathrm{OC}$ 
had contributed to salt leaching. Ammonium contents in guacamole-derived composts were negligible and quite below the WRAP limit (Table 4).

Among nutrients, $\mathrm{P}$ deserves special attention because the current predictions establish that worldwide resources are only available for around 90 more years (Barth et al., 2008) and plant nutrients cannot be replaced by 'alternative nutrients'. In the long run, closed loop management of this element is inevitable and the composts provide an interesting alternative to fulfil this objective. The $\mathrm{P}$ content in the composts can be considered adequate. Tittarelli et al. (2007) indicated that $\mathrm{P}$ content greater than $0.6 \%$ is enough to cover P plant uptake.

The total content of plant macronutrients in guacamole-derived composts were the normal for the different compost types. Compost GR1PW7 showed higher concentrations of $\mathrm{P}, \mathrm{Ca}, \mathrm{Mg}$ because it had a greater poultry manure ratio, but the benefit of this was counterbalanced due to an increased Na content and a decreased N content. Composts GR2PW1 and GR1PW2 showed small differences in nutrient contents. In an ORBIT report using 2007 fertilizer prices, a value of EUR 8.49/tonne fresh matter was calculated as the agronomic value of a similar compost produced from kitchen, food and garden wastes, classified as rich in nutrients $(1.40 \% \mathrm{~N}-0.26 \% \mathrm{P}-0.85 \% \mathrm{~K})$, well structured, and declared as an organic NPK fertiliser (Barth et al., 2008). Building on this evidence, GR2PW1 and GR1PW2 composts could therefore be classified as organic fertilizers rich in nutrients.

The fine-graded composts and the coarse fraction showed heavy metal contents (Table 4) lower than the upper limits established as criteria by the European eco-label for soil improvers (European-Commission, 2006). The obtained values were lower or similar to reported values for green compost, 
vegetable and fruit, garden waste compost, and bio-waste compost from separate collection (IPTS, 2012).

\subsection{Stability and growth tests}

The results of the self-heating test for guacamole-derived composts are shown in Table 5. The temperature increments were very low in all three composts indicating that they could be classified as very stable well-aged composts (Brinton et al., 1995).

Table 5. Results of maturity and phytotoxicity tests for final compost samples having a maximum particle size of $20 \mathrm{~mm}$ : Self-Heating test, germination test with cress (Lepidium sativum) following CEN (2011b) performed in Petri dishes by the direct contact method, and growth bioassay with Chinese cabbage (Brassica napa ssp. Pekinensis) (CEN, 2011a)

\begin{tabular}{|c|c|c|c|c|c|}
\hline Unit & & 2PW1 & GR1PW2 & GR1PW7 & PEAT \\
\hline \multicolumn{6}{|c|}{ SELF-HEATING TEST } \\
\hline$\Delta \mathrm{T}$ & ${ }^{\circ} \mathrm{C}$ & 1.7 & 1.5 & 1.1 & \\
\hline \multicolumn{6}{|c|}{ EN 16086-2:2011 GERMINATION TEST } \\
\hline Germination & $\%$ & $96.7 \mathrm{a}$ & $100 \mathrm{a}$ & $96.7 \mathrm{a}$ & $93.4 \mathrm{a}$ \\
\hline Germination Rate & $\%$ & $103.6 \mathrm{a}$ & $107.1 \mathrm{a}$ & $103.6 \mathrm{a}$ & $100.0 \mathrm{a}$ \\
\hline Root length & $\mathrm{mm}$ & $37.5 \mathrm{a}$ & $43.7 \mathrm{ab}$ & $46.7 \mathrm{ab}$ & $53.0 \mathrm{~b}$ \\
\hline Root length Index & $\%$ & $70.8 \mathrm{a}$ & $82.3 \mathrm{ab}$ & $88.1 \mathrm{ab}$ & $100.0 \mathrm{~b}$ \\
\hline Munoo-Liisa Vitality Index & $\%$ & $73.8 \mathrm{a}$ & $88.3 \mathrm{a}$ & $91.6 \mathrm{a}$ & $100 \mathrm{a}$ \\
\hline \multicolumn{6}{|c|}{ EN 16086-1:2011 PLANT RESPONSE OF CHINESE CABBAGE } \\
\hline Germination at day 7 & $\%$ & $93.4 \mathrm{~b}$ & $95.0 \mathrm{~b}$ & $91.7 \mathrm{~b}$ & $66.7 \mathrm{a}$ \\
\hline Germination at day 14 & $\%$ & $93.4 \mathrm{a}$ & $95.0 \mathrm{a}$ & $93.4 \mathrm{a}$ & $85.0 \mathrm{a}$ \\
\hline Germination Rate day 14 & $\%$ & $109.8 \mathrm{a}$ & $111.8 \mathrm{a}$ & $109.8 \mathrm{a}$ & $100.0 \mathrm{a}$ \\
\hline Fresh weight & g plant ${ }^{-1}$ & $0.211 \mathrm{a}$ & $0.193 \mathrm{a}$ & $0.205 \mathrm{a}$ & $0.205 \mathrm{a}$ \\
\hline
\end{tabular}

Values followed by the same letter in the same line do not differ statistically (Tukey's test, $p<0.05$ )

Results corresponding to the germination test with cress (Lepidium sativum) are shown in Table 5. The Germination Rate in the three composts was similar to that in the peat control, but Root Length Index corresponding to compost GR2PW1 (70.8\%) was lower than that in the peat control. Munoo-Liisa Vitality 
Index, which combines germination and root length was consequently low in GR2PW1 however the difference to the other treatments was not statistically significant. Often, the requirements for testing germination and plant growth are restricted to the more sensitive uses of compost like horticulture, constituents of growing media or potting soils. Eco-label criteria for growing media (EuropeanCommission, 2007) establishes that 'Products shall not adversely affect plant emergence or subsequent growth' but does not establish specific limits. WRAP (2011) guidelines (using tomato seeds) establish a value of at least $80 \%$ of the performance of the control and this limit value was also used for tests with cress (Itavaara et al., 2010). The Munoo-Liisa Vitality Index was below $80 \%$ for compost GR2PW1 which indicated that this compost exhibits some degree of phytotoxicity. Taking into consideration that the cress germination test is a highly sensitive method (Itavaara et al., 2010), the use of GR2PW1 as substrate should not be rejected on this basis. In the case of agricultural uses of compost, the risks derived from phytotoxic components could be considered unlikely due to soil resilience, although the precautionary principle should be applied if heavy or repeated applications were carried out. Results corresponding to the growth test with Chinese cabbage (Brassica rapa ssp. pekinensis) are also shown in Table 5. Cabbage seed germination in composts was faster than in the control substrate as indicated by the lower germination found in control substrate after one week. After 2 weeks, germination was statistically similar in all substrates, although germination rate in the composts was maintained at $\sim 10 \%$ higher than in the control. The cabbage plants grew faster in the peat control, reaching similar size to plants in the composts due to the fertilizer incorporated in the control substrate. Total fresh biomass produced in compost substrates was similar to the control. 


\subsection{Avocado seedling production trial}

The percentage of avocado seeds that germinated three months after sowing was higher in the three compost-based substrates $(93 \%, 87 \%$ and $90 \%$ in the GR1PW7, GR1PW2 and GR2PW1 composts respectively) than in the control treatment $(80 \%)$. The same pattern was observed on the same date when the percentage of avocado plants tall enough to be transplanted was compared between compost (higher than 80) and control (lower than 60) treatments. Nevertheless, due to the reduced number of seeds used per treatment (30) the data should be considered with caution.

Three months after sowing, avocado plant growth (Fig. 3) was satisfactory and similar in the three composts. It shows that a wide range of guacamole wastes:pruning residues ratio can be used in composting piles, according to the availability of these materials. In addition, all growth parameters, leaf area, plant height, number of leaves, and stem diameter, were significantly higher in compost cultivated-plants than those grown in the control substrate, which is often used in the commercial production of avocado nursery plants. The organic components in the control substrate (peat and coconut fibre) lack available nutrients. They usually have a high $\mathrm{C} / \mathrm{N}$ ratio limiting their capacity for nitrogen supply whereas guacamole composts have low $\mathrm{C} / \mathrm{N}$ ratio and are nutrient-rich. However, the differences observed between the plants grown in compost and those grown in the control substrate could be attributed to differences in the composition of the substrates (probably in substances involved in promotion of plant growth) than to the non-application of fertilizers during the experiment. In a previous trial with Topa-Topa avocado seedlings grown in a substrate similar to the control used in this work, plant growth was similar with and without fertilizer application for up 
to four and a half months. Positive effects of compost on plant growth have been previously reported.

The results obtained show that both avocado seed germination and seedling growth in compost-based substrates are adequate with no signs of toxicity due to the compost. Thus, the incorporation of composts in substrates intended for seedling beds could sustain plant growth for a longer time resulting in an increase in the flexibility of time scheduling in the nursery.

[INSERT Fig 3 HERE]

\section{Conclusions}

Composting of guacamole residues using pruning wastes as bulking agent is a feasible treatment option for GR. Windrow composting of GR:PW mixtures followed which can be considered as the classical evolution of the composting process. The composting process seemed not be disturbed by broad changes in the GR:PW ratio (in the tested range 2:1 to $1: 7$ ), and, thus, the composting process of GR could be suitable for small factories lacking well-trained technical staff. Despite the robustness of composting, a GR:PW ratio around 1:2 was recommended to guarantee adequate process evolution, product sanitation, and final composts characteristics. A small amount of poultry manure was incorporated to composting mixtures, although its effect and any benefits were not evident.

Coarse material composed of avocado pits and woodchips remained undecomposed at the end of the composting process. This coarse material can be used for mulching or re-circulated into the composting process once more. Sieved composts obtained were chemically stable and showed moderate nutrient contents. 
The obtained composts fulfilled the more stringent European standards for compost. However, the high $\mathrm{pH}$ observed limits their use as the only component of the growing media. Thus, it is recommended to mix and dilute guacamolederived composts with acidic components when preparing nursery substrates to counteract the high $\mathrm{pH}$. The elevated $\mathrm{pH}$ in end-products may also facilitate $\mathrm{NH}_{3}$ emissions if mixed with $\mathrm{N}$-rich fertilizers.

Similar results could be extrapolated to other avocado processing residues such as those derived from avocado oil extraction reducing pollution and increasing the overall sustainability of avocado derived production.

\section{Acknowledgements}

This work was partially supported by the Operative Program FEDER of the Junta de Andalucía (PAIDI-AGR108, PAIDI-AGR156 and P08-AGR-3694) and Ministerio de Economía y Competitividad - European Regional Development Fund, European Union (AGL2013-43732-R and CTQ2013-46804-C2-1R). The authors wish to thank Mr. Jerome Lock-Wah-Hoon for the English revision of the manuscript.

\section{References}

Barth, J., Amlinger, F., Favoino, E., Siebert, S., Kehres, B., Gottschall, R., Bieker, M., Löbig, A., and Bidlingmaier, W. (2008). "Compost production and use in the EU. Final report of ORBIT e.V. / European Compost Network ECN ". European Commission. DG Joint Research Centre/ITPS, Weimar (GERMANY).

Böhm, R. (2007). Chapter 9 Pathogenic agents. In "Compost Science and Technology" (L. F. Diaz, M. de Bertoldi, W. Bidlingmaier and E. Stentiford, eds.), Vol. 8, pp. 177-200. Elsevier. 10.1016/s14787482(07)80012-1

Bost, J. B., Smith, N. J. H., and Crane, J. H. (2013). History, distribution and uses. In "The Avocado: Botany, Production and Uses" (B. Schaffer, B. N. 
Wolstenholme and A. W. Whiley, eds.). CAB International, Oxfordshire, UK.

Brinton, J. W. F. (2000). "Compost quality standards \& guidelines:An International View. Final Report." New York State Association of Recyclers.

Brinton, W. F., Evans, E., Droffner, M. L., and Brinton, R. B. (1995).

Standardized test for evaluation of compost self-heating. BioCycle 36, 6469.

Carlsbaek, M. (2010). Use of Compost in Horticulture and Landscaping, Ch. 9.9. In "Solid Waste Technology and Management" (T. H. Christensen, ed.). Wiley, Hoboken, NJ, USA.

CEN (1999a). EN 13037. Soil improvers and growing media.Determination of $\mathrm{pH}$. European Committee for Standardization, Brussels.

CEN (1999b). EN 13038. Soil improvers and growing media. Determination of electrical conductivity. European Committee for Standardization, Brussels.

CEN (1999c). EN 13039. Soil improvers and growing media.Determination of organic matter content and ash. European Committee for Standardization, Brussels.

CEN (1999d). EN 13040 Soil improvers and growing media. Sample preparation for chemical and physical tests, determination of dry matter content, moisture content and laboratory compacted bulk density. European Committee for Standardization, Brussels.

CEN (2001). EN 13651. Soil improvers and growing media - Extraction of calcium chloride/DTPA (CAT) soluble nutrients. pp. 17. European Committee for Standardization, Brussels.

CEN (2002). EN 13657. Characterization of waste - Digestion for subsequent determination of aqua regia soluble portion of elements. European Committee for Standardization, Brussels.

CEN (2011a). EN 16086-1:2011. Soil improvers and growing media. Determination of plant response. Part 1: Pot growth test with Chinese cabbage. European Committee for Standardization, Brussels.

CEN (2011b). EN 16086-2:2011. Soil improvers and growing media.

Determination of plant response. Part 2: Petri dish test using cress.

European Committee for Standardization, Brussels.

Ceustermans, A., Coosemans, J., and Ryckeboer, J. (2010). Compost Microbial

Activity Related to Compost Stability. In "Microbes at Work" (H. Insam, I. Franke-Whittle and M. Goberna, eds.), pp. 115-134. Springer, Berlin. 10.1007/978-3-642-04043-6_6

Chang, J. I., Tsai, J. J., and Wu, K. H. (2006). Thermophilic composting of food waste. Bioresource Technology 97, 116-122. http://dx.doi.org/10.1016/j.biortech.2005.02.013

Chou, C. H., and Büyüksönmez, F. (2006). Biogenic emissions from green waste and comparison to the emissions resulting from composting (part 1: ammonia). Compost Science and Utilization 14, 16-22.

Diaz, L. F., and Savage, G. M. (2007). Chapter 4 Factors that affect the process. In "Compost Science and Technology" (L. F. Diaz, M. de Bertoldi, W. Bidlingmaier and E. Stentiford, eds.), Vol. 8, pp. 49-65. Elsevier. 10.1016/s1478-7482(07)80007-8

Dorantes-Alvarez, L., Ortiz-Moreno, A., and García-Ochoa, F. (2012). Avocado. In "Tropical and Subtropical Fruits : Postharvest Physiology, Processing 
and Packaging" (J. Ahmed and M. G. Lobo, eds.), pp. 437-454. Wiley, Somerset, NJ, USA.

European-Commission (2006). 2006/799/EC: Commission Decision of 3

November 2006 establishing revised ecological criteria and the related assessment and verification requirements for the award of the Community eco-label to soil improvers (notified under document number $\mathrm{C}(2006)$

5369) (Text with EEA relevance). In "OJ L 325, 24.11.2006 ", pp. 28-34.

European-Commission (2007). 2007/64/EC, Commission Decision of 15

December 2006 establishing revised ecological criteria and the related assessment and verification requirements for the award of the Community eco-label to growing media (notified under document number C(2006) 6962) (Text with EEA relevance). In " OJ L 32, 6.2.2007 ", pp. 137-143.

FAOSTAT (2014). Agriculture data. Acces date April 2014.

Grundy, A. C., and Bond, B. (2007). Use of Non-living Mulches for Weed Control. In "Non-Chemical Weed Management : Principles, Concepts, and Technology" (M. K. Upadhyaya and R. E. Blackshaw, eds.). CABI Publishing, Wallingford, Oxon, GBR.

Hang, Y. D. (2004). Management and Utilization of Food Processing Wastes. Journal of Food Science 69, CRH104-CRH107. 10.1111/j.13652621.2004.tb13341.x

Houba, V. J. G., Uittenbogaard, J., and Pellen, P. (1996). Wageningen Evaluating Programmes for Analytical Laboratories (WEPAL), organization and purpose. Communications in Soil Science and Plant Analysis 27, 421-431.

IPTS (2012). "Technical report for End-of-waste criteria on Biodegradable waste subject to biological treatment. Third Working Document," Seville, Spain.

Itavaara, M., Vikman, M., Liisa, M., and Vuorinen, A. (2010). Maturity Tests for Composts - Verification Of a Test Scheme for Assessing Maturity. Compost Science \& Utilization 18, 174-183.

Iturriaga, M. H., Arvizu-Medrano, S. M., and Escartin, E. F. (2002). Behavior of Listeria monocytogenes in avocado pulp and processed guacamole. Journal of Food Protection 65, 1745-1749.

Jurado, M. M., Suárez-Estrella, F., Vargas-García, M. C., López, M. J., LópezGonzález, J. A., and Moreno, J. (2014). Evolution of enzymatic activities and carbon fractions throughout composting of plant waste. Journal of Environmental Management 133, 355-364. http://dx.doi.org/10.1016/j.jenvman.2013.12.020

Paradelo, R., Moldes, A. B., and Barral, M. T. (2013). Evolution of organic matter during the mesophilic composting of lignocellulosic winery wastes. Journal of Environmental Management 116, 18-26.

Soong, Y.-Y., and Barlow, P. J. (2004). Antioxidant activity and phenolic content of selected fruit seeds. Food Chemistry 88, 411-417. http://dx.doi.org/10.1016/j.foodchem.2004.02.003

SPSS (2010). "IBM SPSS Statistics 19 Core System User's Guide," Chicago, IL

Tittarelli, F., Petruzzelli, G., Pezzarossa, B., Civilini, M., Benedetti, A., and Sequi, P. (2007). Chapter 7 Quality and agronomic use of compost. In "Compost Science and Technologys" (L. F. Diaz, M. de Bertoldi, W. Bidlingmaier and E. Stentiford, eds.), Vol. Volume 8, pp. 119-157. Elsevier. 10.1016/s1478-7482(07)80010-8

WRAP (2011). "Guidelines for the Specification of Quality Compost for use in Growing Media ", Banbury, UK. 


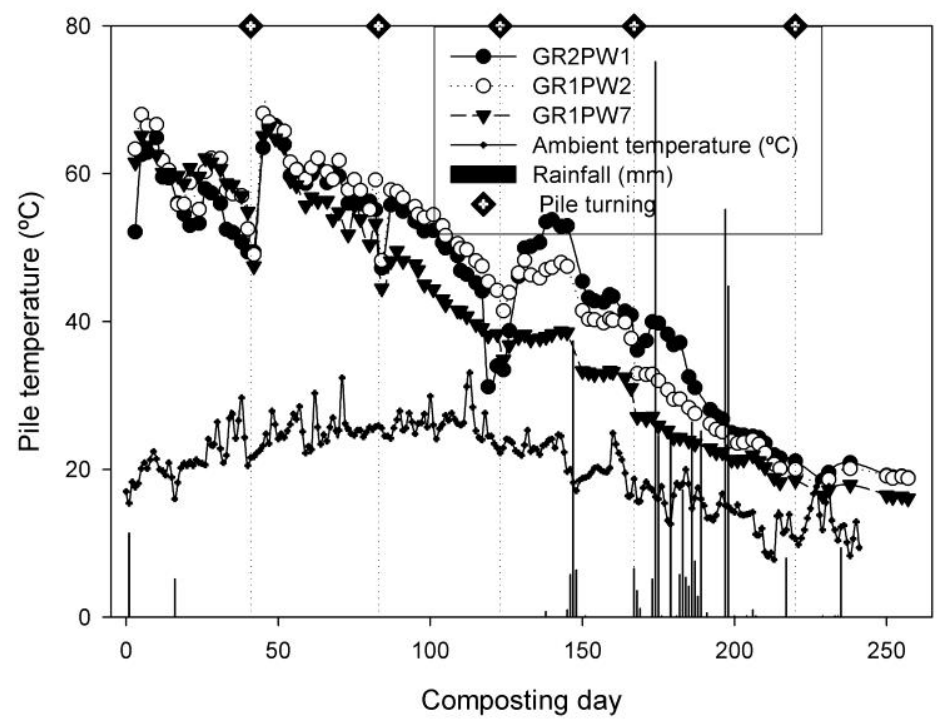

Fig. 1. Temperature evolution in the compost piles 


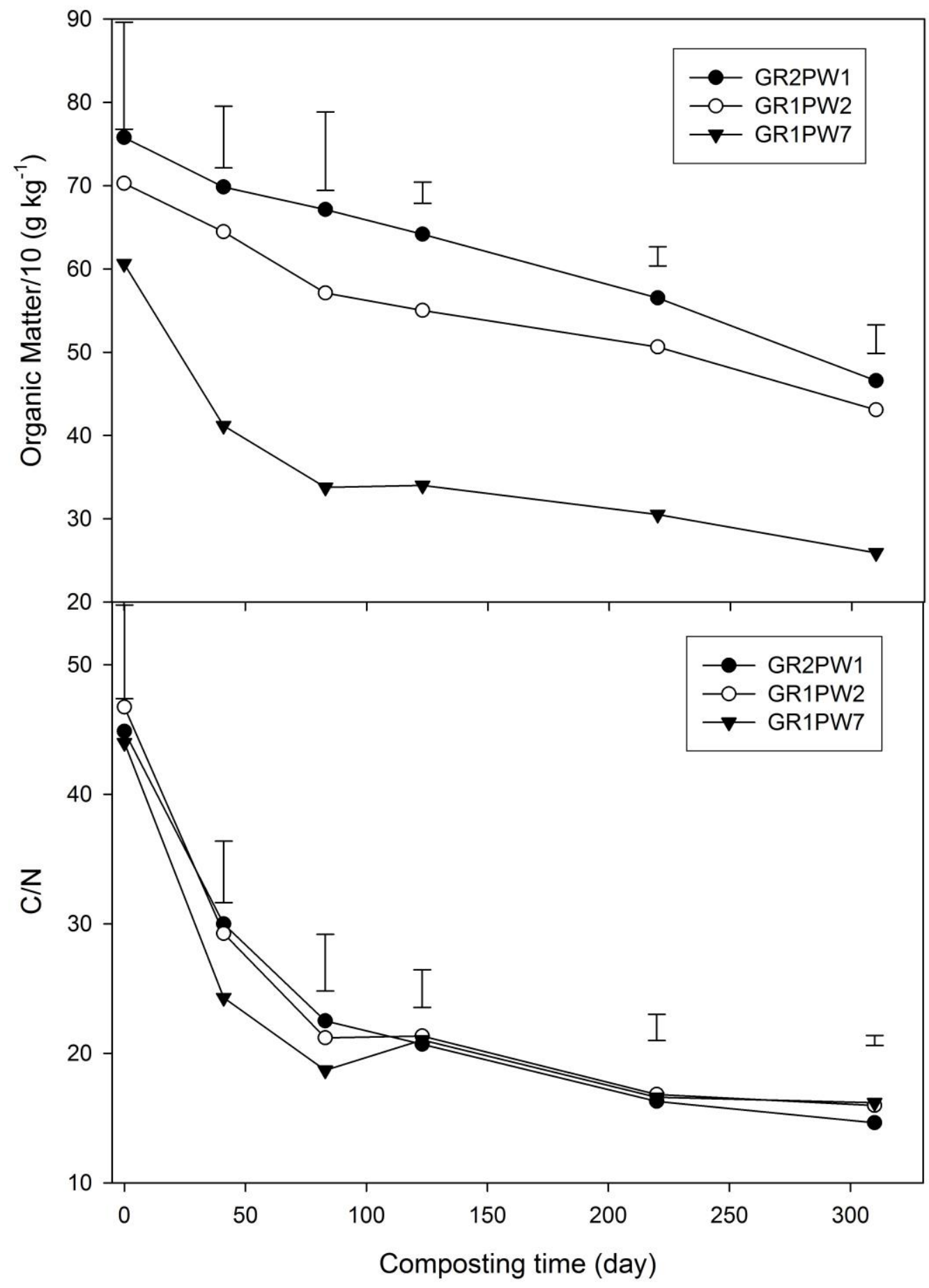

Fig. 2. Organic matter and $\mathrm{C} / \mathrm{N}$ ratio evolution during composting (values are the mean of three replicates and bars are LSD for each composting time) 


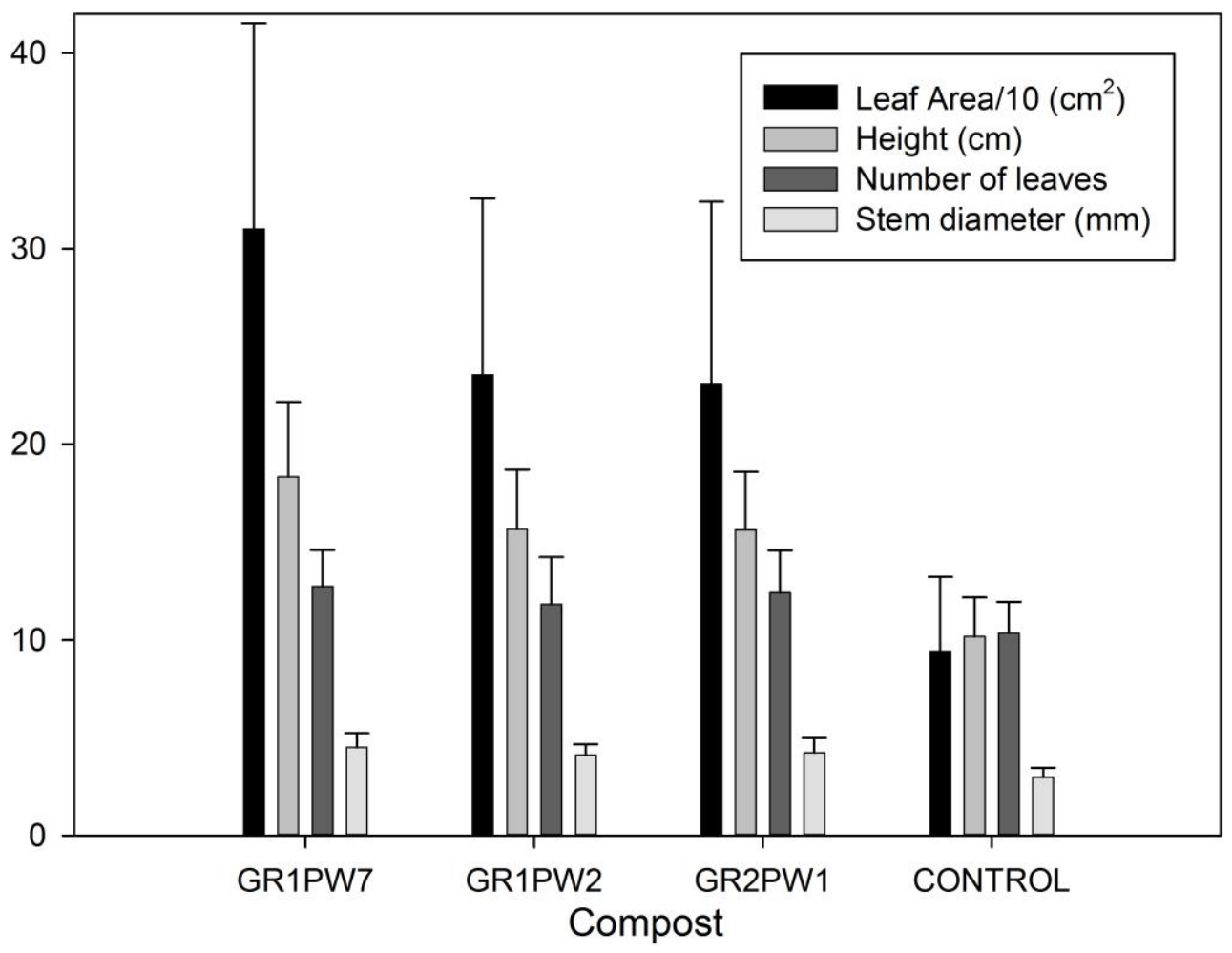

Fig. 3. Growth of avocado seedlings in compost-based substrates 